\title{
Allozyme heterozygosity and fluctuating asymmetry in brown hares Lepus europaeus introduced to New Zealand: Developmental homeostasis in populations with a bottleneck history
}

\author{
Franz SUCHENTRUNK, Günther B. HARTL, John E. C. FLUX, \\ John PARKES, Anita HAIDEN and Stephen TAPPER
}

Suchentrunk F., Hartl G. B., Flux J. E. C., Parkes J., Haiden A. and Tapper S. 1998. Allozyme heterozygosity and fluctuating asymmetry in brown hares Lepus europaeus introduced to New Zealand: Developmental homeostasis in populations with a bottleneck history. [In: Ecological genetics in mammals III. G. B. Hartl and J. Markowski, eds]. Acta Theriologica, Suppl. 5: 35-52.

The effect of genetic variability as indicated by allozyme heterozygosity on developmental homeostasis as expressed by fluctuating morphological asymmetry (FA) is under current debate. Recent studies of brown hares Lepus europaeus Pallas, 1778 in Austria (Hartl et al. 1995) revealed a negative relationship between FA and allozyme heterozygosity in non-metric but not in metric skull characters. We aimed to find out whether non-metric traits of brown hares are generally more prone to FA than metric, or whether metric traits also show increased FA in populations with drastically reduced genetic variability. We studied variation in 34 enzyme systems and the relationship between overall individual heterozygosity based on polymorphic loci and FA in 27 non-metric and six metric bilateral skull characters of 96 brown hares from three populations in Britain and two in New Zealand. All brown hares in New Zealand are considered to be descendents of only six founding individuals from Britain and were expected to have considerably reduced gene pool variability. Only six polymorphic loci were found. Allozyme heterozygosity in the New Zealand populations was not significantly lower than in British populations. However, both the New Zealand and the British populations had significantly lower genetic variability than the Austrian populations studied earlier. This suggested a (historic) genetic bottleneck in British brown hares having preceeded the one in hares in New Zealand. It corresponds to the hypothesis of the deliberate introduction of brown hares to Britain by the ancient Romans. Neither at the individual nor at the population level was there any significant relationship between FA and allozyme heterozygosity. Despite the significantly reduced genetic variability in hares from New Zealand and Britain, their population-specific levels of non-metric and metric FA were significantly lower than in hares from Austria. This might result eg, from genetic drift following the founding event in Britain, or from stronger selection against hares with low developmental homeostasis in Britain and New Zealand than in Austria, due to environmental differences. The study demonstrates that in brown hares reduced genetic variability is not necessarily connected with low levels of developmental homeostasis as the earlier study of Austrian populations might have suggested. Rather, the particular phylogeny of populations has to be taken into account, when interpreting relationships between developmental homeostasis and genetic variability.

Research Institute of Wildlife Ecology, Vienna Veterinary University, Savoyenstr. 1, A-1160 Wien, Austria, e-mail: franz.suchentrunk@vu-wien.ac.at, fax: ++43 14890959 
(FS, AH); Institut für Haustierkunde, Universität Kiel, Olshausenstraße 40, D-24118 Kiel, Germany (GBH); Ecological Research Associates, Silverstream, P.O. Box 48147 Upper Hutt, New Zealand (JECF); Manaaki Whenua-Landcare Research, P.O. Box 69 Lincoln, New Zealand (JP); The Game Conservancy Trust, Fordingbridge, Hampshire SP6 1EF, England, U.K. (ST)

Key words: Lepus europaeus, heterozygosity, fluctuating asymmetry, developmental homeostasis

\section{Introduction}

Developmental homeostasis is considered to indicate the state of adaptation of a population (eg Jones 1987, Graham et al. 1993). The dependence of developmental homeostasis on genetic variability is a contentious topic in evolutionary biology (eg Mitton and Grant 1984, Leary et al. 1985, Palmer and Strobeck 1986, Leary et al. 1992, Novak et al. 1993, Hoffmann and Parsons 1994, Mitton 1995). Developmental homeostasis is expressed by fluctuating morphological asymmetry (FA) and genetic diversity commonly by allozyme heterozygosity (eg Palmer and Strobeck 1986, Zakharov 1993). One controversial issue in this context concerns the "poikilotherm-homeotherm hypothesis", which refers to the presence of a negative relationship between FA and allozyme heterozygosity in poikilothermic but not in homeothermic animals (Handford 1980, Wooten and Smith 1986). However, differences between homeotherms and poikilotherms might be partly due to the fact that in earlier studies non-metric characters have mainly been used in poikilotherms and metric ones in homeotherms for correlation with heterozygosity (Hartl et al. 1995).

In brown hare Lepus europaeus Pallas, 1778 populations from Austria a negative correlation between FA and allozyme heterozygosity was found, but only in non-metric skull characters and not in metric ones (Hartl et al. 1995). Moreover, it was only present in adult individuals at the population level and not at the individual level within populations. This indicates that in brown hares different morphological systems are affected to different extents by developmental homeostasis and during different phases of life.

To test whether it is a general phenomenon in brown hares that non-metric characters are more prone to FA under diminished gene pool variability than metric, we studied populations that have passed a severe demographic bottleneck and thus should have considerably reduced allozyme variability. We chose natural populations of brown hares from New Zealand, where hares were introduced deliberately by the end of the last century (Flux 1990). Available records indicate that all hares naturalized in New Zealand were from Phillip Island (Victoria, Australia), a place were no more than six hares from Britain were released in 1863. Unrecorded additional liberations of brown hares in New Zealand using animals from other provenences in Europe cannot be excluded, but are not likely because the source population established already on Phillip Island provided 
acclimatized animals closer at hand than those from Europe. Thus, all brown hares currently widely distributed on the two main islands are probably descendants of a very restricted founder population (Flux 1990). We also included populations from Britain in our study, because British brown hares are considered a different subspecies (L.e. occidentalis) to the central European brown hares L. e. europaeus (Flux 1990).

We expected reduced allozyme variability but higher FA in non-metric characters in hares from New Zealand when compared to hares from Britain and Austria. Furthermore, with the inclusion of the post-bottleneck populations of New Zealand in the correlation analysis, we expected a negative relationship between FA and allozyme heterozygosity to be noticeable in the metric character system also.

\section{Material and methods}

\section{Samples, morphological and biochemical-genetic characters}

This study is based on 104 brown hares collected at three localities (operationally called populations) in Britain in February 1995 and two in New Zealand in September/October 1993 and in

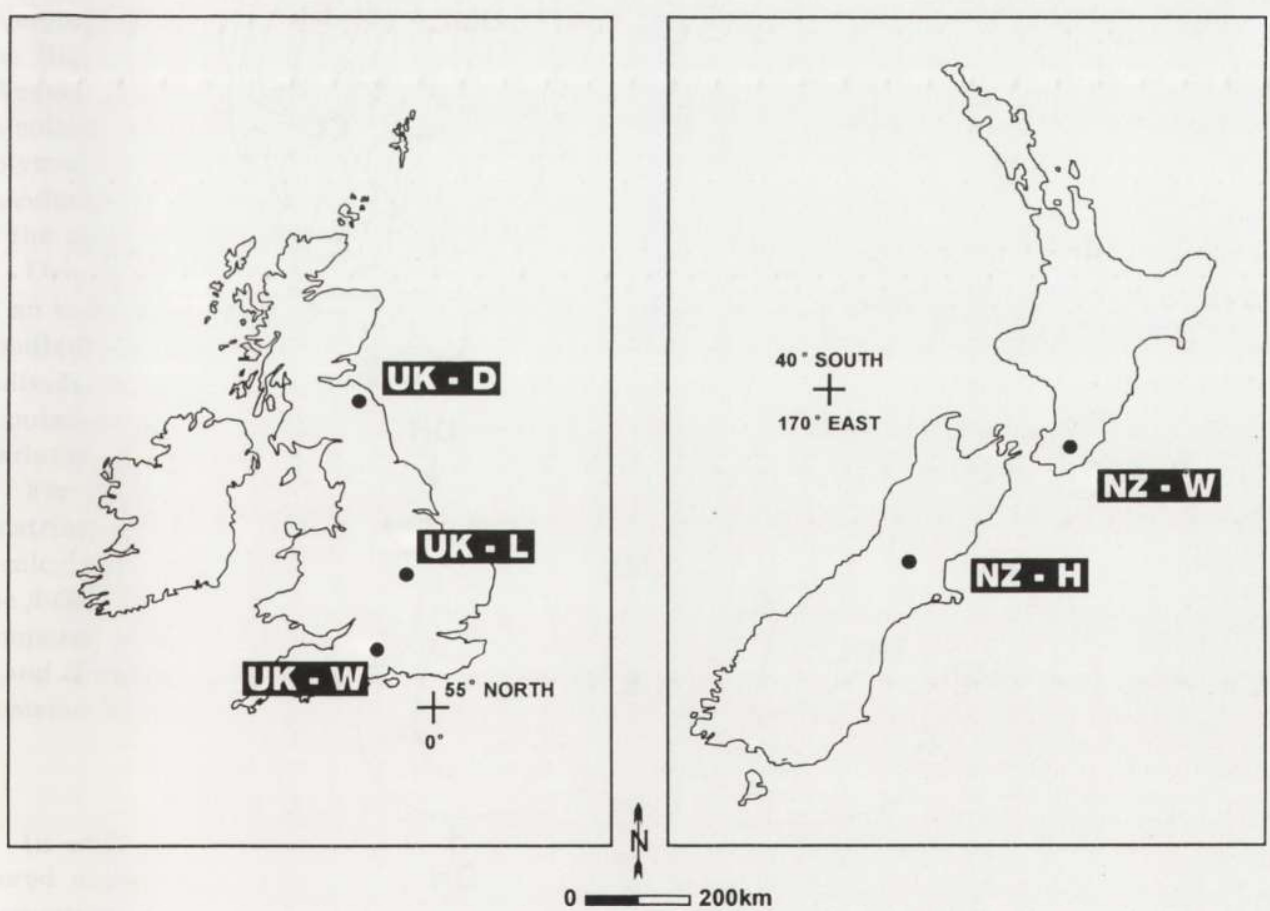

Fig. 1. Sampling localities (populations) of brown hares in Britain and New Zealand; sample size in parenthesis. UK-W - Wiltshire, England $(n=18)$, UK-L - Loddington, England $(n=19)$, UK-D Duns, Scotland $(n=15)$, NZ-W - Wairarapa region, New Zealand $(n=25)$, NZ-H - Harper/Avoca catchment, New Zealand $(n=19)$. 
February/March 1995 (Fig. 1). All could be used for genetic analysis but because of some severely damaged skulls only 96 were included in the morphological analyses. Only adult-sized hares where used. Adults were defined as individuals lacking the lateral epiphyseal protrusion on the ulna (Stroh 1931) and were considered six months of age or older (Suchentrunk et al. 1991). Sex was deternined by inspection of the internal reproductive organs. Tissue samples of heart, kidney, liver and spleen were taken from each specimen and maintained at $-20^{\circ} \mathrm{C}$ until processed. For assessing FA of individuals a total of 27 bilateral non-metric skull characters were scored and nine bilateral netric characters were taken on both sides of the cleaned skulls and lower jaws. Digital calipers were used
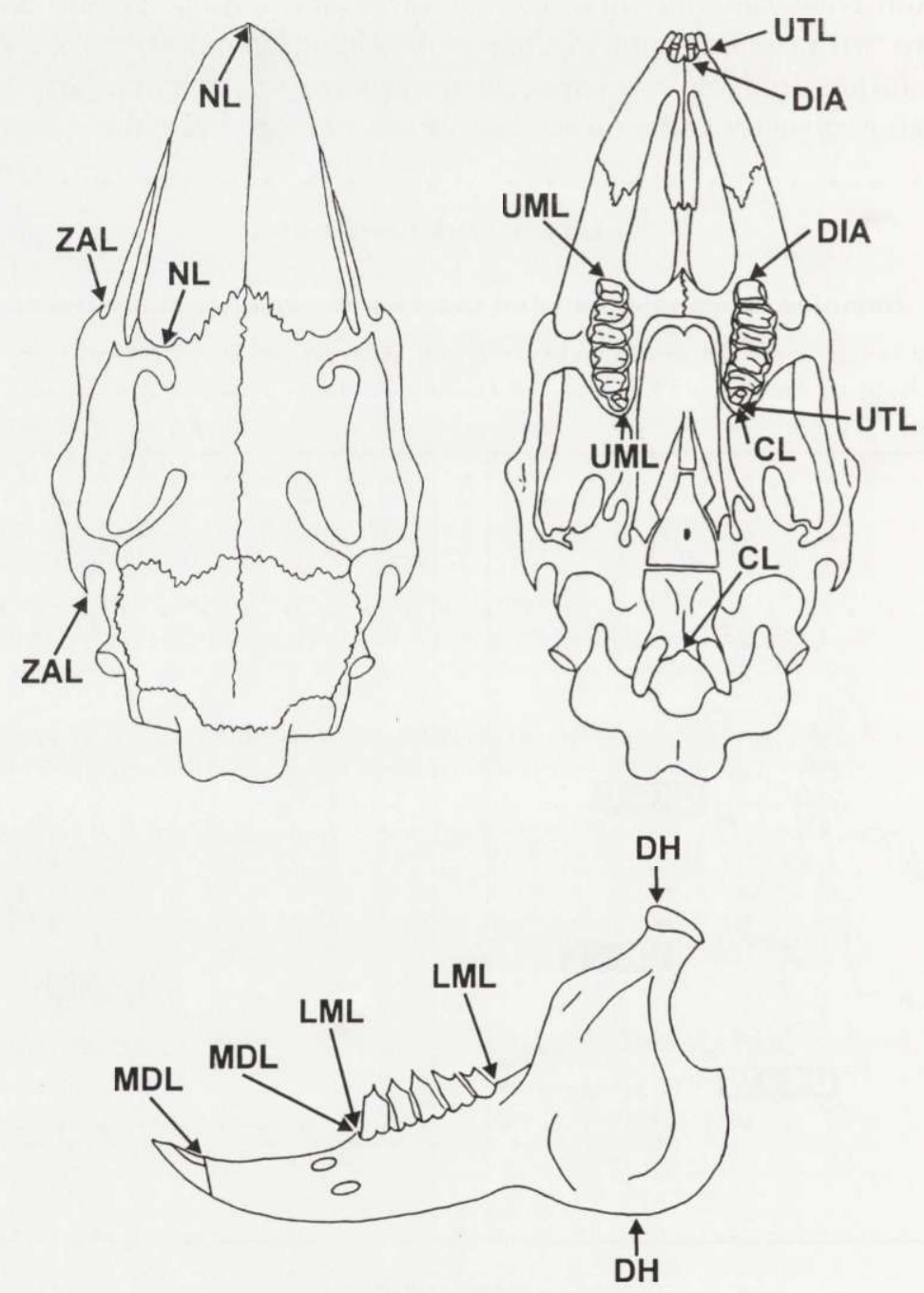

Fig. 2. Bilateral metric skull characters. CL - cranium length, DH - dentale height, DIA - diastema length, LML - lower molar row length, MDL - mandibula diastema length, NL - nasal length, UML - upper molar row length, UTL - upper teeth row length, ZAL - zygomatic arch length. Arows indicate the two respective points for taking measurements. 
to measure to the nearest $0.01 \mathrm{~mm}$. All characters were scored/measured by one author (FS) exclusively. Non-metric characters are detailed in Appendix 1; for metric characters see Fig. 2. All these characters are identical with those studied earlier in brown hares from Austria (Hartl et al. 1995). In rare cases, single characters could not be scored/measured in certain specimens due to partial damage of skulls/ mandibles.

Horizontal starch gel electrophoresis was applied to resolve allozymic variation in 34 enzyme systems encoded by 52 hypothetical structural gene loci (Appendix 2). The enzyme suite is identical to the ones studied in Austrian brown hare populations (Hartl et al. 1993, 1995, Suchentrunk 1993), except for B-GAL and ACY-1, which have not been included in the current study.

Tissue preparation, electrophoresis and protein specific staining followed Hartl and Höger (1986 and Grillitsch et al. (1992). Genetic interpretation of band-patterns was consistent with the principles outlined by Harris and Hopkinson (1976) and Hillis and Moritz (1990). For resolving allelic variants direct side-by-side comparison of migrating allozymes was carried out including samples of the five populations and samples of Austrian hares studied earlier (Hartl et al. 1993) on the same gels. Designation of alleles was carried out by adopting the nomenclature of Hartl et al. (1993). The genotypes at polymorphic loci were determined in each specimen.

\section{Allozyme heterozygosity, rate of polymorphism and Shannon-Weaver information function of allozyme diversity}

Allele frequencies, average observed heterozygosity based on all loci screened $\left(H_{o}\right)$, proportion of polymorphic loci $(P, 99 \%$ criterion) and tests for significant deviation of genotypes from the Hardy-Weinberg distribution, based on exact probabilities, were based on all 104 hares and calculated using the BIOSYS-1 pc package, release 1.7 (Swofford and Selander 1989). Additionally, the Shannon-Weaver information function of allozyme diversity ( $H^{\prime}$; eg Hedrick 1985, Hartl et al. 1994) was calculated in each population involving all polymorphic loci. Independence of genotypes among the polymorphic loci was tested by $G$-tests. In cases of significant association of genotypes of two loci the calculation of the Shannon-Weaver information function was based on the two-dimensional frequencies of the associated genotypes of the respective loci.

Overall individual heterozygosity $\left(H_{\mathrm{I}}\right)$ calculated by dividing the number of all heterozygous loci of an individual by the number of loci found to be polymorphic in this study. For comparing the five populations, mean population-specific $H_{\mathrm{I}}\left(\bar{H}_{\mathrm{I}}\right)$ was calculated as the arithmetic mean over all individuals used also for asymmetry analyses $(n=96)$. Significant variation of $\bar{H}_{\mathrm{I}}$ across the populations and between sexes was tested by a two-way ANOVA of arc-sine transformed $H_{\mathrm{I}}$ values. Variation of $P$ across the five populations was tested for significance by a $G$-test.

For comparing the genetic variability of the five populations studied presently with the 20 Austrian brown hare populations studied earlier, $H_{o}, P$ and $H$ of the latter populations were recalculated using the data base published already (Hartl et al. 1993, 1995) by omitting the Acy-1 and the $\beta$-Gal loci to adjust to the present set of loci. However, $\bar{H}_{\mathrm{I}}$ values of the Austrian hares were not compared with those from Britain and New Zealand due to different numbers of polymorphic loci. $H_{o}$, $P$ and $H$ values of hares from New Zealand and Great Britain were compared to respective values of Austrian hares by Kruskal-Wallis tests.

\section{Fluctuating asymmetry in non-metric skull characters (F $\left.\mathbf{A}_{\mathrm{NM}}\right)$}

In each non-metric character absence or presence of asymmetry was scored. Asymmetry was scored whenever character states differed between right and left sides of the skull. Occurrence of fluctuating (FA) or directional asymmetry (DA) was checked by a series of Wilcoxons matched pairs signed-rank tests, applying sequential Bonferroni procedures with a nominal $\alpha$ of 0.05 to correct the critical values for multiple tests (Rice 1989). Such Bonferroni procedures (with $\alpha=0,05$ ) were also used in all following analyses involving single non-metric and metric characters as well as series of tests involving $H_{\mathrm{I}}, P$ and $H$. Since DA was not found in any of the characters, all of them could be 
used as indicators of developmental homeostasis (Palmer and Strobeck 1986). In single characters sex dependence of FA, pairwise association of FA and variation of FA across the five populations were tested by $\chi^{2}$ - and Fishers exact tests. The coefficient of concordance (Kendalls W) of FA of the 27 characters across the populations (PAP - "population asymmetry parameter"; Soulé 1967) was calculated as outlined by Soulé and Baker (1968). Inter-individual variability (IV) of each character was calculated as the standard deviation of scores of the right side of each individual. IV of each character was calculated for the combined sample and for each population separately. Variation of IV across populations was tested by a Friedmann test. Correlation between IV and the tendency of single characters to show FA was tested by a two-tailed Spearmans correlation analysis, whereby the tendency of single characters to show FA was calculated as the percentage of individuals with asymmetry in the respective character.

Overall non-metric FA of an individual (FANM) was calculated as the percentage of characters asymmetric per individual (Leary et al. 1985). The population-specific index of $\mathrm{FA}_{\mathrm{NM}}\left(\overline{\mathrm{FA}}_{\mathrm{NM}}\right)$ was calculated as the arithmetic mean of all individual FANM values for each population. A two-way ANOVA of arc-sine transformed FANM values was used to test for significant variation across populations and between sexes. $\overline{\mathrm{FA}}_{\mathrm{NM}}$ of hares of Britain and New Zealand were tested for significant difference to $\overline{\mathrm{FA}}_{\mathrm{NM}}$ in four Austrian regional samples (Table 5; Hartl et al. 1995) by a Kruskal-Wallis test.

\section{Fluctuating asymmetry in metric skull characters (FAM)}

To estimate the influence of measurement error on metric asymmetry in single characters, each right and left side measurement was taken twice in 30 randomly chosen skulls. This produced a data set of 120 measurements ( 30 skulls $\times 2$ sides $\times 2$ measurements) in each metric character. In each metric character the respective data set was subjected to a two-way ANOVA with individual and side as effects. The ratio of the sum of mean squares of the side component and of the side-individual interaction component of variance to the residual served as an indicator of the relative influence of measurement error on asymmetry (Hartl et al. 1995). If the residual was less than half the sum of mean squares of the side and the side-individual-interaction component of variance the influence of the measurement error on asymmetry was considered negligible.

In each character, occurrence of DA was checked by a matched pairs signed-rank test (right vs left measurement) and antisymmetry by testing frequency distributions of right-left paired differences for significant deviation from an expected normal distribution by Kolmogorov-Smirnov tests (Palmer and Strobeck 1986).

To check for possible ontogenetic dependence of asymmetry (influence of growth on FA), size dependence of FA of single characters was examined using Spearmans rank correlations between absolute values of right-left differences and associated arithmetic means.

Asymmetry of single characters was calculated as

$$
\frac{|\mathrm{r}-1|}{(\mathrm{r}+1) / 2}
$$

where ( $\mathrm{r}$ and 1 are the right- and left-side measurements. This index accounts for potential size dependence of asymmetry (Palmer and Strobeck 1986). Due to occurrence of DA in three characters (DHL, MDL, NL; Fig. 2) only six metric characters (CL, DIA, LML, UML, UTL, ZAL, Fig. 2) were selected for further analyses. Variation of asymmetry of single metric characters due to sex and population was tested by two-way ANOVAs (Willig and Owen 1986). The coefficient of concordance of FA among characters across the populations ("PAP") was calculated as in non-metric charcters.

In each individual an overall index of metric fluctuating asymmetry (FAM) was calculated as the arithmetic mean over all asymmetry values of the six characters. The population-specific index of $\mathrm{FAM}$ $\left(\overline{\mathrm{FA}}_{\mathrm{M}}\right)$ was calculated as the arithmetic mean of all $\mathrm{FA}_{\mathrm{M}}$-values of the respective population. Variation of $\overline{\mathrm{FA}}_{\mathrm{M}}$ across populations and between the sexes was tested by a two-way ANOVA. $\overline{\mathrm{FA}}_{\mathrm{M}}$ of British and New Zealand brown hares were tested for significant differences to $\overline{\mathrm{FA}}_{\mathrm{M}}$ in four Austrian regional samples of brown hares (Table 5; Hartl et al. 1995) by a Kruskal-Wallis test. 


\section{Relationship between non-metric and metric FA}

At the level of single characters the relationship of FA of non-metric and metric characters was studied by Kruskal-Wallis tests. They were carried out for both the whole combined sample (all populations) and separately for each population. Correlation of $F A_{N M}$ and $F A_{M}$ within and among populations was tested by Spearmans rank correlations.

Relationships between heterozygosity, rate of polymorphism, Shannon-Weaver information function and fluctuating asymmetry

At the individual level, relationships between $H_{1}$ and $\mathrm{FA}_{\mathrm{NM}}$ and between $H_{1}$ and $\mathrm{FA}_{\mathrm{M}}$ were examined by two-tailed Spearman's rank correlations. Relationships between single-locus heterozygosity and FA were tested by Kruskal-Wallis tests. Also, Kruskal-Wallis tests were carried out for testing variation of individual $\mathrm{FA}_{\mathrm{NM}}$ and $\mathrm{FA}_{\mathrm{M}}$ across genotypes at polymorphic loci. These tests were done for each population and for the combined sample (including all individuals of the five populations). Relationships among the estimators of population-specific allozyme diversity used $\left(H_{\mathrm{l}}, P, H\right)$ and between each of these estimators and the population-specific $\overline{\mathrm{FA}}_{\mathrm{NM}}$ and $\overline{\mathrm{FA}}_{\mathrm{M}}$ were analyzed by two-tailed Spearman's rank correlations.

\section{Results}

\section{Allozyme polymorphism, heterozygosity and diversity}

Enzyme polymorphism was detected at six loci (Idh-2, Es-1, Acp-1, Pep-2, Ada-2, $\mathrm{Mpi}$ ), with two alleles at each of these loci (Table 1). Means of observed single-locus heterozygosities $(h)$ are given in Table 1. Significant $(p=0.003)$ deviation of genotypes from Hardy-Weinberg expectations in favour of homozygotes was found at the $E s-1$ locus in the NZ-W population. A significant $(p=0.001)$ association of genotypes at the Es-1 and Pep-2 loci was found in the combined sample of individuals of all populations that showed polymorphism at these two loci. Values of allozyme variability $\left(H_{O}, P, H\right)$ based on all loci as well as $H_{\mathrm{I}}$ (based on polymorphic loci only) are given for each population in Table 2; for comparison, the respective values of 20 Austrian brown hare populations (Hartl et al. 1993, 1995), recalculated for the same set of loci, are also given in Table 2. However, $H_{\mathrm{I}}$ values of the Austrian populations are not listed because of the higher number

Table 1. Genetic variability in brown hares of New Zealand and Britain: polymorphic loci with alleles occurring in at least one of the populations studied and corresponding enzyme systems screened. $h$ - mean of observed single-locus heterozygosity across the five populations, SD - standard deviation.

\begin{tabular}{lll}
\hline Locus (alleles) & $h$ (SD) & Enzyme system (abbreviaton, E.C. number) \\
\hline Idh-2 $(100,130)$ & $0.011(0.02)$ & Isocitrate dehydrogenase (IDH, 1.1.1.42) \\
Es-1 $(-100,-75)$ & $0.350(0.23)$ & Esterases (ES, 3.1.1.1) \\
Acp $-1(100,50)$ & $0.013(0.03)$ & Acid phosphatase (ACP, 3.1.3.2) \\
$P e p-2(100,104)$ & $0.258(0.16)$ & Peptidases (PEP, 3.4.11) \\
Ada-2 $(100,75)$ & $0.403(0.14)$ & Adenosine deaminase (ADA, 3.5.4.4) \\
$M p i(100,84)$ & $0.039(0.06)$ & Mannosephosphate isomerase (MPI, 5.3.1.8) \\
\hline
\end{tabular}


Table 2. Allozyme variability in five populations of brown hares from New Zealand and Britain. $H_{0}-$ average observed heterozygosity (based on all 52 loci screened); $P$ - rate of polymorphism $99 \%$ criterion), $H^{\prime}$ - Shannon-Weaver information function of allozyme diversity, $\bar{H}_{1}$ - average individual heterozygosity based on the six polymorphic loci. For acronyms of populations see Fig. 1. The respective values (mean, SD, range) of 20 local populations of brown hares from Austria are given for comparison (20A); calculation of the latter values are based on the data sets published in Hartl et al. (1993) and Hartl et al. (1995) but omitting the Acy-1 and the $\beta$-Gal loci to adjust to the present data set. $\bar{H}_{\mathrm{I}}$ values of the Austrian populations are not indicated for comparison because they were tased on more polymorphic loci (Hartl et al. 1995).

\begin{tabular}{|c|c|c|c|c|c|}
\hline \multicolumn{2}{|c|}{ Population } & $H_{o}$ & $P$ & $H^{\prime}$ & $\bar{H}_{\mathrm{I}}$ \\
\hline \multicolumn{2}{|l|}{ NZ-W } & 0.019 & 7.7 & 1.792 & 0.153 \\
\hline \multicolumn{2}{|l|}{ NZ-H } & 0.013 & 5.8 & 1.496 & 0.090 \\
\hline \multicolumn{2}{|c|}{ UK-W } & 0.026 & 7.7 & 1.679 & 0.214 \\
\hline \multicolumn{2}{|l|}{ UK-L } & 0.017 & 3.8 & 1.336 & 0.143 \\
\hline \multicolumn{2}{|l|}{ UK-D } & 0.024 & 7.7 & 1.816 & 0.200 \\
\hline \multirow{4}{*}{$20 \mathrm{~A}$} & Mean & 0.034 & 13.7 & 2.901 & \\
\hline & $\mathrm{SD}$ & 0.007 & 2.2 & 0.333 & \\
\hline & Min & 0.023 & 9.6 & 2.119 & \\
\hline & $\operatorname{Max}$ & 0.055 & 19.2 & 3.631 & \\
\hline
\end{tabular}

of polymorphic loci in these Austrian populations; this prevented direct comparison. $H_{\mathrm{I}}$ did not vary significantly between sexes or among the five populations from New Zealand and Britain. $H_{0}, P$ and $H$ were significantly ( $\left.p=0.0014-0.0\right) 07$ ) lower in the hares from New Zealand and Britain compared to the Austrian populations.

At the population level mean $H_{\text {I }}$ was significantly positively correlated with $H_{O}$ $\left(r_{\mathrm{S}}=+1.0, p<0.0005\right)$ but not with $P$ and $H^{\prime}$ in the five populations analyzed. Consequently, in addition to $H_{\mathrm{I}}$, we used $P$ and $H^{\prime}$ as separate indices of alloz/me variability for correlation analyses involving $\mathrm{FA}$ at the population level.

\section{Fluctuating asymmetry in non-metric characters}

No non-metric character showed DA; hence, all could be used for measuring FA. At the level of single characters there was no sex dependence and no pairvise association of FA when tested separately for the five populations and for the total sample. The tendencies of single non-metric characters to show FA are listed in Table 3 for the combined samples of hares from New Zealand and Britain. Significant variation of FA across the five populations occurred only in NM15 $(p=0.0009)$ and NM18 $(p=0.00001)$. No significant concordance of $\mathrm{F}_{\Delta}$ of non-metric characters (PAP; Kendall's W $=0.052 ; p=0.226$ ) across the populatons was detected. FA of single characters was highly positively correlated with the IV value $\left(r_{\mathrm{S}}=+0.76, p=0.0001, n=27\right)$. However, no significant variation of $\mathrm{IV}$ of 
Table 3. Tendencies of non-metric morphologic characters (NM 1-27, see Appendix 1) to show asymmetric expression (FANM) of brown hares from New Zealand and Britain. Percentage frequencies of hares with bilateral asymmetry in each of the 27 characters are given for the combined sample of hares from New Zealand (NZ) and Britain (UK), respectively. A - weighted mean of percentage frequencies of individuals with respective asymmetric character expression over four geographic units of Austrian hares for comparison (Hartl et al. 1995). $n$-sample size.

\begin{tabular}{|c|c|c|c|c|c|}
\hline \multirow{2}{*}{$\begin{array}{l}\text { Nonmetric } \\
\text { character }\end{array}$} & \multicolumn{2}{|c|}{$\mathrm{NZ}$} & \multicolumn{2}{|c|}{ UK } & \multirow{2}{*}{$\frac{\mathrm{A}}{\mathrm{FA}_{\mathrm{NM}}}$} \\
\hline & $\mathrm{FA}_{\mathrm{NM}}$ & $n$ & FANM & $n$ & \\
\hline NM 1 & 13.6 & 44 & 25.0 & 52 & 29.7 \\
\hline NM 2 & 36.4 & 44 & 48.1 & 52 & 34.1 \\
\hline NM 3 & 16.7 & 42 & 30.8 & 52 & 16.1 \\
\hline NM 4 & 31.7 & 41 & 34.6 & 52 & 54.8 \\
\hline NM 5 & 19.5 & 41 & 1.9 & 52 & 27.2 \\
\hline NM 6 & 7.1 & 42 & 9.8 & 51 & 16.8 \\
\hline NM 7 & 12.5 & 40 & 15.4 & 52 & 24.3 \\
\hline NM 8 & 25.0 & 44 & 30.8 & 52 & 23.9 \\
\hline NM 9 & 9.1 & 44 & 11.5 & 52 & 16.1 \\
\hline NM10 & 25.6 & 43 & 36.5 & 52 & 30.6 \\
\hline NM11 & 15.9 & 44 & 13.5 & 52 & 26.5 \\
\hline NM12 & 7.5 & 40 & 5.8 & 52 & 2.2 \\
\hline NM13 & 11.4 & 44 & 17.6 & 51 & 30.9 \\
\hline NM14 & 0.0 & 44 & 9.6 & 52 & 0.0 \\
\hline NM15 & 34.1 & 44 & 23.1 & 52 & 27.8 \\
\hline NM16 & 25.0 & 44 & 21.2 & 52 & 23.1 \\
\hline NM17 & 2.3 & 43 & 2.0 & 51 & 2.7 \\
\hline NM18 & 15.9 & 44 & 23.5 & 51 & 17.3 \\
\hline NM19 & 20.5 & 44 & 7.9 & 51 & 12.6 \\
\hline NM20 & 0.0 & 44 & 0.0 & 52 & 0.6 \\
\hline NM21 & 0.0 & 44 & 0.0 & 52 & 0.6 \\
\hline NM22 & 0.0 & 44 & 0.0 & 52 & 3.2 \\
\hline NM23 & 0.0 & 44 & 0.0 & 52 & 0.6 \\
\hline NM24 & 25.6 & 43 & 18.0 & 50 & 23.4 \\
\hline NM25 & 0.0 & 44 & 1.9 & 52 & 0.5 \\
\hline NM26 & 5.7 & 44 & 6.1 & 49 & 5.0 \\
\hline NM27 & 11.6 & 43 & 5.8 & 52 & 5.5 \\
\hline
\end{tabular}

single characters across populations occurred which otherwise could have influenced population-specific FA values.

Population-specific indices of FANM ( $\left.\overline{\mathrm{FA}}_{\mathrm{NM}}\right)$ are listed in Table 5 along with the range of the respective values found in four regional samples of Austrian brown hares (Hartl et al. 1995) for comparison. $\overline{\mathrm{FA}}_{\mathrm{NM}}$ varied significantly across the populations $(p=0.042)$ but there was no sex dependence in the combined sample or in any single population. $\overline{\mathrm{FA}}_{\mathrm{NM}}$ of British and New Zealand brown hares was significantly $(p=0.014)$ lower than in the four Austrian regional samples (Table 5). 


\section{Fluctuating asymmetry in metric characters}

Three characters (DH, MDL, NL) were excluded from further analyses of FAM because of occurrence of DA. In each of the six remaining characters measurement error was negligible for calculating asymmetry (Table 4). For characterizing the tendencies of single characters to show FA, the mean FA value of each of the six remaining characters calculated over all individuals, respectively, is given in Table 4. In each metric character, FA was independent of age.

In no character did FA vary significantly across populations or between sexes. The coefficient of concordance of FA among characters across populations (PAP; Kendalls W) did not differ significantly from zero. The population-specific indices of FA of metric characters $\left(\overline{\mathrm{FA}}_{\mathrm{M}}\right)$ are listed in Table 5; they did not vary significantly between sexes or across populations. Also listed in Table 5 is the range of $\overline{\mathrm{FA}}_{\mathrm{M}}$ in four Austrian brown hare regional samples for comparisn. $\overline{\mathrm{FA}}_{\mathrm{M}}$ of British and New Zealand brown hares was significantly $(p=0.023)$ lower than $\overline{\mathrm{FA}}_{\mathrm{M}}$ of the four Austrian regional samples (Table 5; Hartl et al. 1995).

Table 4. Mean individual fluctuating asymmetry (FA) of single metric traits (codes) in each population (upper number) and associated standard error of the mean (lower number); sample sizes in parentheses. For codes of metric characters and calculation of FA of single characters see Material and methods section. ME - influence of measurement error on FA (for details see Material and methods section); for population acronyms see Fig. 1. A - weighted mean of mean FA-values of respective metric characters of hares of four regional samples from Austria for comparison (Hartl et al. 1995).

\begin{tabular}{lccccccc}
\hline $\begin{array}{c}\text { Metric trait } \\
\text { (code) }\end{array}$ & ME & NZ-W & NZ-H & UK-W & UK-L & UK-D & A \\
\hline CL & $2.6: 1$ & 0.007 & 0.006 & 0.006 & 0.009 & 0.007 & 0.007 \\
& & 0.001 & 0.001 & 0.001 & 0.002 & 0.001 & \\
DIA & & $(25)$ & $(19)$ & $(18)$ & $(19)$ & $(15)$ & \\
& $9.7: 1$ & 0.007 & 0.010 & 0.011 & 0.007 & 0.008 & 0.009 \\
& & 0.001 & 0.002 & 0.002 & 0.001 & 0.001 & \\
LML & $(25)$ & $(18)$ & $(18)$ & $(19)$ & $(14)$ & \\
& & 0.011 & 0.010 & 0.011 & 0.011 & 0.006 & 0.012 \\
& & 0.002 & 0.003 & 0.002 & 0.003 & 0.001 & \\
UML & $(24)$ & $(18)$ & $(17)$ & $(18)$ & $(12)$ & \\
& $26.4: 1$ & 0.009 & 0.008 & 0.007 & 0.008 & 0.011 & 0.016 \\
& & 0.002 & 0.002 & 0.001 & 0.002 & 0.001 & \\
UTL & $(25)$ & $(18)$ & $(18)$ & $(19)$ & $(15)$ & \\
& & & & & & \\
& $8.5: 1$ & 0.004 & 0.008 & 0.004 & 0.006 & 0.005 & 0.006 \\
ZAL & & 0.001 & 0.001 & 0.001 & 0.001 & 0.001 & \\
& & $(25)$ & $(18)$ & $(18)$ & $(19)$ & $(15)$ & \\
& $84.5: 1$ & 0.007 & 0.006 & 0.007 & 0.006 & 0.007 & 0.003 \\
& & 0.001 & 0.001 & 0.001 & 0.002 & 0.002 & \\
& & $(23)$ & $(16)$ & $(17)$ & $(17)$ & $(15)$ & \\
\end{tabular}


Table 5. Relationship between level of individual fluctuating asymmetry of non-metric (FANM) or metric $\left(\mathrm{FA}_{\mathrm{M}}\right)$ skull characters and individual overall heterozygosity $\left(H_{\mathrm{I}}\right)$ of brown hares in each population. $r_{\mathrm{S}}-$ Spearman correlation coefficients for two-tailed tests. $\overline{\mathrm{FA}}_{\mathrm{NM}}-$ population-specific mean non-metric fluctuating asymmetry, $\overline{\mathrm{FA}}_{M}$ - population-specific mean metric fluctuating asymmetry. For population acronyms see Fig. 1. Number of individuals per population is given in parentheses. A - range of respective FA values of brown hares of four Austrian regional samples for comparsion (Hartl et al. 1995). ${ }^{a}$ Spearman correlation coefficient not significant.

\begin{tabular}{lcccccc}
\hline & \multicolumn{7}{c}{ Populations } \\
\cline { 2 - 7 } & $\begin{array}{c}\text { NZ-W } \\
(25)\end{array}$ & $\begin{array}{c}\text { NZ-H } \\
(19)\end{array}$ & $\begin{array}{c}\text { UK-W } \\
(18)\end{array}$ & $\begin{array}{c}\text { UK-L } \\
(19)\end{array}$ & $\begin{array}{c}\text { UK-D } \\
(15)\end{array}$ & A \\
\hline$r_{\mathrm{S}}\left(\mathrm{FA}_{\mathrm{NM}} / H_{\mathrm{I}}\right)$ & $-0.23^{\mathrm{a}}$ & $0.36^{\mathrm{a}}$ & $-0.06^{\mathrm{a}}$ & $-0.28^{\mathrm{a}}$ & $0.10^{\mathrm{a}}$ & \\
$r_{\mathrm{S}}\left(\mathrm{FA}_{\mathrm{M}} / H_{\mathrm{I}}\right)$ & $-0.24^{\mathrm{a}}$ & $-0.08^{\mathrm{a}}$ & $0.08^{\mathrm{a}}$ & $-0.19^{\mathrm{a}}$ & $-0.10^{\mathrm{a}}$ & \\
$\overline{\mathrm{FA}}_{\mathrm{NM}}$ & 0.12 & 0.15 & 0.14 & 0.11 & 0.16 & $0.161-0.177$ \\
$\overline{\mathrm{FA}}_{\mathrm{M}}$ & 0.008 & 0.008 & 0.009 & 0.008 & 0.008 & $0.009-0.010$ \\
\hline
\end{tabular}

\section{Relationship between non-metric and metric FA}

There was no significant relationship between the FA of single non-metric and metric characters when examined both in the total sample or in each of the five populations separately. Likewise, overall FANM and FAM of individuals were not significantly correlated when studied in the combined sample or in each population separately. Finally, at the population level $\overline{\mathrm{FA}}_{\mathrm{NM}}$ and $\overline{\mathrm{FA}}_{\mathrm{M}}$ were also not significantly correlated.

\section{Relationships between heterozygosity and FA}

At the individual level, neither FANM nor FAM varied across genotypes of polymorphic loci. Also, neither FANM nor FAM showed a significant correlation with $H_{\mathrm{I}}$ when tested for the total sample combining all individuals and for each population separately (Table 5). Again, at the population level there was neither a significant correlation between $\bar{H}_{\mathrm{I}}$ and $\overline{\mathrm{FA}}_{\mathrm{NM}}$ nor between $\bar{H}_{\mathrm{I}}$ and $\overline{\mathrm{FA}}_{\mathrm{M}}$ (Table 6 ). These results remained the same when tests were carried out using $P$ and $H$ values instead of $\bar{H}_{\mathrm{I}}$ as population-specific estimators of enzyme diversity.

Table 6. Relationship $\left(r_{\mathrm{S}}-\right.$ Spearman correlation coefficients, two-tailed tests) between fluctuating asymmetry and mean overall heterozygosity of brown hares at the population level. $\left(\bar{H}_{1}-\right.$ mean overall heterozygosity calculated over 6 polymorphic loci, $\overline{\mathrm{FA}}_{\mathrm{NM}}-$ mean overall fluctuating asymmetry calculated over 27 non-metric skull-characters, $\overline{\mathrm{FA}}_{\mathrm{M}}$ - mean overall fluctuating asymmetry calculated over six metric skull-characters).

\begin{tabular}{ccc}
\hline & $\overline{\mathrm{FA}}_{\mathrm{NM}}$ & $\overline{\mathrm{FA}}_{\mathrm{M}}$ \\
\hline $\bar{H}_{\mathrm{I}}$ & $r_{\mathrm{S}}=0.200(p=0.75, n=5)$ & $r_{\mathrm{S}}=0.354(p=0.56, n=5)$ \\
\hline
\end{tabular}




\section{Discussion}

We did not find a significant relationship between allozyme heterozygosity and fluctuating asymmetry (FA) in brown hares from New Zealand and Britain. Such a relationship was absent in both character systems (non-metric and metric) and in each single character. Different levels of FA of single characters suggest differences in developmental stability and canalisation; but even in single characters with relatively high levels of FA no dependence of FA on heterozygosity was found. Also, there were no associations of FA of any non-metric and metric characters at the individual and population level. Thus, the paucity of a significant relationship between developmental homeostasis and genetic variability is not likely to be due to any specific functional importance of some morphological characters or charecter systems.

A significant relationship between FA and heterozygosity was not only absent at the population level but also at the individual level within each of the five populations exposed to different environments. Hence, a possible differential perceptibility of such a relationship due to varying environmental contexts, as demonstrated for the fish Gambusia holbrooki by Mulvey et al. (1994), obviously does not confound the present findings at the individual level. However, at the population level the existence of a negative correlation between FA and heterozygosity might be concealed by different levels of environmental stress (Pamer and Strobeck 1986). For studying the relationship between FA and heterozygosity at the population level a perfect correlation should be present for the statisical test to reject the null hypothesis with only five populations envolved presertly. However, there was not even the tendency of a negative correlation (no negative sign of the $r_{\mathrm{S}}$ values). This suggests that this result is not due to the low nunber of populations considered.

In addition to allozyme heterozygosity we used the rate of polymorphisn $(P)$ and the Shannon-Weaver information function $\left(H^{\prime}\right)$ to characterize the geretic variability of the populations. The latter two indices are considered more senstive indicators of reduced gene pool variability, particularly in post-bottleneck pppulations (Hedrick 1985, Leberg 1992, Hartl and Pucek 1994). Their use should portray the gene pool variability more reliably and hence might increase the chunce of detecting a negative correlation with FA. But employing these indices in addtion to heterozygosity values in correlation analyses with FA did not change the realts in essence. In some earlier studies (eg Leary et al. 1983), negative correlatons were found between FA and heterozygosity when the latter was both averiged over all polymorphic loci and when it was considered at single loci. Presently the lack of a relationship between FA and heterozygosity was independent of oth protein-specific heterozygosity and general genetic variability as indicated by ovirall heterozygosity, rate of polymorphism and Shannon-Weaver information inde:.

Unexpectedly, not only hares from New Zealand have depauperated gene prols; the hares of all three British populations also show the same low levd of 
heterozygosity (Table 2). The significantly lower level of gene pool variability as compared to those of Austrian populations (Hartl et al. 1993, 1995) is particularly indicated by the rates of polymorphism $(P)$ and the Shannon Weaver indices $\left(H^{\prime}\right)$ in all populations of New Zealand and Britain; they all are below the respective minimum values of the 20 Austrian populations (Table 2). In contrast, average observed heterozygosity $\left(H_{0}\right)$ of two British populations (UK-D, UK-W; Table 2) exceeded the minimum values of Austrian brown hare populations. These findings accord to theoretical considerations and experimental results in vertebrate populations (eg Leberg 1992, Hartl and Pucek 1994), which predict particularly reduced $P$ values but not necessarily low $H_{O}$ levels in post-bottleneck populations. Further genetic details which will be published elsewhere will demonstrate that the gene pools of the brown hares from Britain and New Zealand are closely related to those of central European brown hares. The major difference between hares from Britain and New Zealand and those from central Europe is due to a loss of many alleles which are present in central European populations (F. Suchentrunk, unpubl.). Thus, despite the current taxonomical view of separate subspecies (see introduction section), there is no objection as regards the degree of divergence of gene pools in our comparison of developmental homeostasis.

The present data (Table 2) demonstrate that no significant loss of genetic variability has occurred in hares from New Zealand as compared to hares from Britain, in spite of the reported dramatic demographic bottleneck of the founder population on Phillip Island. Rather, a general loss of genetic variability has happened already in brown hares from Britain: in none of the three populations ranging from Scotland to south England is there any hint of a "normal" level of genetic variability as it was found in hares from central Europe (Hartl et al. 1990, 1992, 1993). This finding agrees with the hypothesis of the deliberate introduction of brown hares to the Britsh Isles by the ancient Romans, well after the opening of the Channel and the separation of the British Isles from the continent (Arnold 1993). Liberations of hares at that time might have been based on few individuals representing the founder population of all brown hares spread out today throughout Britain. Hence, the essential genetic bottleneck in the hares studied presently probably has already occurred some 2000 years ago. Alternatively, brown hares with low genetic variability could have invaded Britain before the opening of the Channel via the natural landbridge connecting the Britsh Isles with todays continental Europe some 8000 years BP.

Irrespective of the cause of the low genetic variability of the brown hares from Britain and New Zealand as compared to central European populations, the present study demonstrates that in the brown hare low gene pool variability or low allozyme heterozygosity per se does not necessarily lead to a decrease of homeostasis as it has been expected from the findings in Austrian brown hares (Hartl et al. 1995) and might be expected according to the hypotheses of overdominant selection of protein loci or associative overdominance (eg Charlesworth and Charlesworth 1987, Nei 1987, Mitton 1993). Generally, different evolutionary 
histories in different suites of populations might affect the relationship between developmental homeostasis and genetic variability in different ways.

Although we cannot rule out completely a certain counteracting effect of particularly favourable environmental conditions (eg Pankakoski 1985), we consider it unlikely that all the diverse environments to which the currently studied populations from Britain and New Zealand are exposed, counteract exactly to such a degree that it has resulted eventually in the same level of FA.

New Zealand hares show increased levels of ovarial tumors and cysts as well as an increased frequency of missing posterior upper molars as compared to brown hares from Britain and other European regions (Flux 1965, 1980, Parkes 1988, see also Suchentrunk et al. 1992). This suggests some inbreeding depression in hares from New Zealand due to dominance of recessive deleterious alleles. It is, however, not at all paralleled by reduced developmental homeostasis. This indicates a differential effect of gene pool erosion on different fitness components in brown hares.

Apart from New Zealand, brown hares were liberated successfully in diverse regions of the world including tropical (eg Réunion, Barbados) and subantarctic (Falkland Islands) environments (Flux and Angermann 1990). In New Zealand they occupy not only optimal habitats in favourable lowland country but also subalpine (Parkes 1984) and even rather harsh alpine environments; though only low numbers occur in the latter (Flux 1967). This demonstrates the generally high adaptability of brown hares to differing environmental contexts, even though they have experienced a severe genetic bottleneck.

The significantly higher level of developmental stability of brown hares in New Zealand and Britain as compared to populations from continental Europe (Austria) might eg, result from a genetic drift following the founding event in Britain. However, no data on the heritability of morphological fluctuating asymmetry (and developemtal homeostasis) in hares are available. It might equally well be due to different levels of selection against low developmental homeostasis by the different environments, resulting in proportionally higher mortality of leverets or juveniles with low developmental stability in Britain and New Zealand. Irrespective of the reason of "normal" or even increased developmental stability in hares from New Zealand, the results suggest well adapted populations of brown hares in New Zealand. This, however, does not necessarily mean that these hares have the same level of evolutionary potential as the brown hares from central Europe, which display higher genetic variability.

Acknowledgements: We are grateful to "Manaaki Whenua - Landcare Research" (Lower Hutt and Christchurch, New Zealand) and to "The Game Conservancy Trust" (Fordingbridge, Hampshire, England) for providing facilities. Special thanks are also due to Mr Hunter, (Masterton, New Zealand), Mr A. Puttik (Middle Woodford, Wiltshire, England), Mr Brockless (Loddington, Leicestershire, England) and to "Bain of Tarves - Catering Butchers, Game and Venison Exporters" (Tarves, Aberdeenshire, Scotland) for organizing shoots and supplying hares. Mrs M. M. Flux (Lower Hutt, New Zealand), Mr M. Coleman, (Christchurch, New Zealand), Mrs M. Trebilco, Mr J. Long, Mr S. Moreby and $\mathrm{Mr}$ C. Stoate (Fordingbridge, England) helped with the organisation work or provided otherwise valuable help. Two anonymous reviewers of an earlier version of the manuscript improved the paper. 
Statistical advices were given by $\mathrm{Mr} \mathrm{R}$. Willing and graphical work was carried out by $\mathrm{Mr} \mathrm{A}$. Körber (both Vienna Veterinary University).

\section{References}

Arnold H. R. 1993. Atlas of mammals in Britain. ITE research publ. no. 6. London, HMSO: 1-145.

Charlesworth D. and Charlesworth B. 1987. Inbreeding depression and its evolutionary consequences. Annual Review of Ecology and Systematics 18: 237-268.

Flux J. E. C. 1965. Incidence of ovarian tumors in hares in New Zealand. Journal of Wildlife Management 29: 622-624.

Flux J. E. C. 1967. Hare numbers and diet in an alpine basin in New Zealand. Proceedings of the New Zealand Ecological Society 14: 27-33.

Flux J. E. C. 1980. High incidence of missing posterior upper molars in hares (Lepus europaeus) in New Zealand. New Zealand Journal of Zoology 7: 257-259.

Flux J. E. C. 1990. Brown hare. [In: The handbook of New Zealand mammals. C. King, ed]. Oxford University Press, Auckland: 161-172.

Flux J. E. C. and Angermann R. 1990. The hares and jackrabbits, [In: Rabbits, hares and pikas Status survey and conservation action plan. J. A. Chapman and J. E. C. Flux, eds]. IUCN Gland: 66-94.

Graham J. F., Freeman D. C. and Emlen J. M. 1993. Developmental stability: a sensitive indicator of populations under stress. [In: Environmental toxicology and risk assessment: ASTM Special Technical Publications No. 1179. W. G. Landis, G. S. Hughes and M. A. Lewis, eds]. American Society for Testing and Materials, Philadelphia: 136-158.

Grillitsch M., Hartl G.B., Suchentrunk F. and Willing R. 1992. Allozyme evolution and the molecular clock in the Lagomorpha. Acta Theriologica 37: 1-13.

Handford P. 1980. Heterozygosity at enzyme loci and morphological variation. Nature 304: 261-262.

Harris H. and Hopkinson D. A. 1976. Handbook of enzyme electrophoresis in human genetics. North-Holland Publ. Co., Amsterdam.

Hartl G. B. and Höger H. 1986. Biochemical variation in purebred and crossbred strains of domestic rabbits Oryctolagus cuniculus L. Genetic Research (Cambridge) 48: 27-34.

Hartl G. B. and Pucek Z. 1994. Genetic depletion in the European bison (Bison bonasus) and the significance of electrophoretic heterozygosity for conservation. Conservation Biology 8: 167-174.

Hartl G. B., Markowski J., Kovács G., Grillitsch M. and Willing R. 1990. Biochemical variation and differentiation in the brown hare (Lepus europaeus) of Central Europe. Zeitschrift für Säugetierkunde 55: 186-193.

Hartl G. B., Markowski J., Świątecki A., Janiszewski T. and Willing R. 1992. Genetic diversity in the Polish brown hare Lepus europaeus Pallas, 1778: implications for conservation and management. Acta Theriologica 37: 15-25.

Hartl G. B., Suchentrunk F., Nadlinger K. and Willing R. 1993. An integrative analysis of genetic differentiation in the brown hare Lepus europaeus based on morphology, allozymes, and mitochondrial DNA. [In: Ecological genetics in mammals II. G. B. Hartl and J. Markowski, eds]. Acta Theriologica 38, Suppl. 2: 33-57.

Hartl G. B., Suchentrunk F., Willing R. and Petznek R. 1995. Allozyme heterozygosity and fluctuating asymmetry in the brown hare (Lepus europaeus): A test of the developmental homeostasis hypothesis. Philosophical Transactions of the Royal Society of London. Biological Series 350: 313-323.

Hartl G. B., Willing. R. and Nadlinger K. 1994. Allozymes in mammalian population genetics and systematics: Indicative function of a marker system reconsidered. [In: Molecular Ecology and Evolution: Approaches and Applications. B. Schierwater, B. Streit, G. P. Wagner and R. DeSalle, eds]. Birkhäuser, Basel: 136-158. 
Hedrick P. W. 1985. Genetics of populations. Jones and Bartlett Publications, Boston and Portola Valley: 1-629.

Hillis D. M. and Moritz C. 1990. Molecular systematics. Sinaur Associates, Inc. Publications, Sunderland: $1-588$.

Hoffmann A. A. and Parsons P. A. 1994. Evolutionary genetics and environmental stress. Oxford Science Publications. Oxford University Press, Oxford.

Jones J. S. 1987. An asymmetrical view of fitness. Nature 325: 298-299.

Leary R. F., Allendorf F. W. and Knudsen K. L. 1983. Developmental stability and enzyme heterozygosity in rainbow trout. Nature 301: 71-72.

Leary R. F., Allendorf F. W. and Knudsen K. L. 1985. Inheritance of meristic variation and the evolution of developmental stability in rainbow trout. Evolution 39: 308-314.

Leary R. F., Allendorf F. W. and Knudsen K. L. 1992. Genetic, environmental, and developmental causes of meristic variation in rainbow trout. [In: Developmental stability in natural populations. V. M. Zakharov and J. H. Graham, eds]. Acta Zoologica Fennica 191: 79-98.

Leberg P. L. 1992. Effects of population bottlenecks on genetic diversity as measured by allozyme electrophoresis. Evolution 46: 477-494.

Mitton J. B. and Grant M. C. 1984. Associations among protein heterozygosity, growth rate, and developmental homeostasis. Annual Review of Ecology and Systematics 15: 479-499.

Mitton J. B. 1993a. Enzyme heterozygosity, metabolism, and developmental stability. Genetica 89: $47-65$.

Mitton J. B. 1993b. Theory and data pertinent to the relationship between heterozygosity and fitness. [In: The natural history of inbreeding and outbreeding, theoretical and empirical perspectives. $\mathrm{N}$. W. Thornhill, ed]. The University of Chicago Press, Chicago and London: 17-41.

Mitton J. B. 1995. Enzyme heterozygosity and developmental stability. [In: Ecological genetics in mammals II. G. B. Hartl and J. Markowski, eds]. Acta Theriologica, Suppl. 3: 33-54.

Mulvey M., Keller G. P. and Meffe G. P. 1994. Single- and multi-locus genotypes and life-history responses of Gambusia holbrooki reared at two temperatures. Evolution 48: 1810-1819.

Nei M. 1987. Molecular evolutionary genetics. Columbia University Press, New York: 1-512.

Novak J. M., Rhodes O. E. Jr, Smith M. H. and Chesser R. K. 1993. Morphological asymmetry in mammals: genetics and homeostasis reconsidered. [In: Ecological genetcs in mammals. G. B. Hart] and J. Markowski, eds]. Acta Theriologica 38, Suppl. 2: 7-18.

Palmer R. A. and Strobeck C. 1986. Fluctuating asymmetry: Measurement, analysis, patterns. Annual Review of Ecology and Systematics 17: 391-421.

Pankakoski E. 1985. Epigenetic asymmetry as an ecological indicator in muskrats. Journal of Mammalogy 66: 52-57.

Parkes J. P. 1984. Home ranges of radio-telemetred hares (Lepus capensis) in a sub-alpine population in New Zealand: implications for control. Acta Zoologica Fennica 171: 279-281.

Parkes J. P. 1988. Missing posterior upper molars in Lepus europaeus in New Zealand. Lagomorph Newsletters 7: 12.

Rice W. S. 1989. Analyzing tables of statistical tests. Evolution 43: 223-225.

Soulé M. E. 1967. Phenetics of natural populations. Asymmetry and evolution in a lizard. American Naturalist 101: 141-160.

Soulé M. E. and Baker B. 1968. Phenetics of natural populations. IV. The population asymmetry parameter in the butterfly Coenonympha tullia. Heredity 23: 611-614.

Stroh G. 1931. Zwei sichere Altersmerkmale beim Hasen. Berliner Tierärztliche Wochenchrift 47: 180-181.

Suchentrunk F., Willing R. and Hartl G. B. 1991. On eye lens weights and other age criteria of the Brown hare (Lepus europaeus Pallas,1778). Zeitschrift für Säugetierkunde 56: 365-374.

Suchentrunk F., Markowski J., Janiszewski T. and Hartl G. B. 1992. Dental and cranial anomalies in Austrian and Polish brown hare Lepus europaeus populations. Acta Theriologica 37: 241-257. 
Suchentrunk F. 1993. Variability of minor tooth traits and allozymic diversity in brown hare Lepus europaeus populations. [In: Ecological genetics in mammals II. G. B. Hartl and J. Markowski, eds]. Acta Theriologica 38, Suppl. 2: 59-69.

Swofford D. L. and Selander R. B. 1989. BIOSYS-1. A computer program for the analysis of allelic variation in population genetics and biochemical systematics. Release 1.7. Users manual. Illinois Natural History Survey, Champaign.

Willig M. R. and Owen R. D. 1986. Fluctuating asymmetry in the cheetah: methodological and interpretative concerns. Evolution 41: 225-227.

Wooten M. C. and Smith M. H. 1986. Fluctuating asymmetry and genetic variability in a natural population of Mus musculus. Journal of Mammalogy 67: 725-732.

Zakharov V. M. 1993. Appearance, fixation and stabilisation of environmentally induced phenotypic changes as a microevolutionary event. Genetica 89 : 227-234.

Received 23 March 1998, accepted 30 April 1998. 
Appendix 1. Non-metric bilateral skull characters used for assessing fluctuating asymmetry. Code, morphological designation and description of character states are given.

NM1 Foramen nervi hypoglossi internale: 0 - two f. present, 1 - three or more f. present

NM2 Foramen nervi hypoglossi internale accessorium: 0 - $\mathrm{f}$. absent, 1 - one f. present, 2 - two or more f. present

NM3 Foramen condylare: $0-f$. absent, 1 - one or more $f$. present

NM4 Foramen basioccipitale laterale: 0 - $\mathrm{f}$. absent, 1 - one $\mathrm{f}$. present, 2 - two or more $\mathrm{f}$. present

NM5 Foramen alisphenoidale: $0-\mathrm{f}$. absent, 1 - one f. present, 2 - two or more $f$. present

NM6 Fenestra orbitalis: $0-\mathrm{f}$. absent, $1-$ one or more f. present

NM7 Foramina circumoptica: 0-1-6 f. present, 1 - more than 6 f. present

NM8 Foramen ethmoidale accessorium: $0-f$. absent, 1 - one or more $f$. present

NM9 Foramen palatinum majus: $0-\mathrm{f}$. absent, 1 - one $\mathrm{f}$. present, 2 - two or more $f$. present

NM10 Foramen intermaxillare: $0-\mathrm{f}$. absent, 1 - one or more $\mathrm{f}$. present

NM11 Foramen processus intermaxillaris: $0-f$. absent, 1 - one or two $f$. present

NM12 Foramen zygomaticum anterius: $0-\mathrm{f}$. absent, 1 - one or more f. present

NM13 Foramen zygomaticum: 0 - $\mathrm{f}$. absent, 1 - one f. present, 2 - two or more f. present

NM14 Processus nasalis ossis intermaxillaris: $0-p$. shorter than or reaching the nasofrontal suture, $1-\mathrm{p}$. exceeding the nasofrontal suture

NM15 Formalen frontale mediale: $0-f$. absent, 1 - one or more $f$. present

NM16 Foramen frontale postorbitale: $0-f$. absent, 1 - one or more f. present

NM17 Foramen fossae articularis mandibularis ossis temporalis: $0-\mathrm{f}$. absent, 1 - one f. present, 2 - more than one $f$. present

NM18 Foramen mentale accessorium: 0 - $\mathrm{f}$. absent, 1 - one f. present, 2 - more than one $\mathrm{f}$. present

NM19 Foramen mandibulare: 0 - f. absent, 1 - one f. present, 2 - two f. present

NM20 Expression of $\mathrm{I}^{2}: 0-\mathrm{I}^{2}$ present, 1 - additional $\mathrm{I}^{2}$ present, $2-\mathrm{I}^{2}$ absent

NM21 Additional upper molar: 0 - a.u.m. absent, 1 - a.u.m. present

NM22 Expression of $\mathrm{M}^{3}: 0-\mathrm{M}^{3}$ absent, $1-\mathrm{M}^{3}$ present

NM23 Additional lower molar: 0 - a.l.m. absent, 1 - a.l.m. present

NM24 Fenestra temporalis: $0-\mathrm{f}$. absent, $1-\mathrm{f}$. present

NM25 Processus palatinus accessorius: $0-$ p. absent, $1-$ p. present

NM26 Foramen basisphenoideo-pterygoideum: $0-\mathrm{f}$. absent, $1-\mathrm{f}$. present

NM27 Foramen temporale: $0-f$. absent, 1 - one or more $f$. present

Appendix 2. Enzyme systems screened for allelic variation (abbreviation, EC number of enzyme and corresponding loci scored in parentheses):

$\alpha$-glycerophosphate dehydrogenase (GDC, 1.1.1.8, Gdc), sorbitol dehydrogenase (SDH, 1.1.1.14, $S d h$ ), lactate dehydrogenase (LDH, 1.1.1.27, Ldh-1, -2), malate dehydrogenase (MOR, 1.1.1.37, Mor-1, -2), malic enzyme (MOD, 1.1.1.40, Mod-1, -2), isocitrate dehydrogenase (IDH, 1.1.1.42, Idh-1, -2), 6-phosphogluconate dehydrogenase, (PGD, 1.1.1.44, Pgd), glucose dehydrogenase (GDH, 1.1.1.47, Gdh-2), glucose-6-phosphate dehydrogenase (GPD, 1.1.1.49, Gpd), glyceraldehyde-3-phosphate dehydrogenase (GAPDH, 1.2.1.12, Gapdh), xanthine dehydrogenase (XDH, 1.2.3.2, Xdh), glutamate dehydrogenase (GLUD, 1.4.1.3, Glud), NADH-diaphorase (DIA, 1.6.2.2, Dia-1), catalase (CAT, 1.11.1.6, Cat), superoxide dismutase (SOD, 1.15.1.1, Sod-1, -2), purine nucleoside phosphorylase (NP, 2.4.2.1, Np), aspartate aminotransferase (AAT, 2.6.1.1, Aat-1, -2), hexokinase (HK, 2.7.1.1, Hk-1, -2, -3), pyruvate kinase (PK, 2.7.1.40, Pk-1), creatine kinase (CK, 2.7.3.2, Ck-1, -2), adenylate kinase (AK, 2.7.4.3, Ak-1, -2), phosphoglucomutase (PGM, 2.7.5.1, Pgm-1, -2, -3), esterases (ES, 3.1.1.1, Es-1; 4.2.1.1, Es-D), acid phosphatase (ACP, 3.1.3.2, Acp-1, - 2, -3), fructose-1,6-diphosphatase (FDP, 3.1.3.11, Fdp-1), peptidases (PEP, 3.4.11, Pep-1, -2), guanine deaminase (GDA, 3.5.4.3, Gda), adenosine deaminase (ADA, 3.5.4.4, Ada-2, -3), aldolase (ALDO, 4.1.2.13, Aldo), fumarate hydratase (FH, 4.2.1.2, Fh), aconitase (ACO, 4.2.1.3, Aco-1, -2), mannose phosphate isomerase (MPI, 5.3.1.8, Mpi), glucose phosphate isomerase (GPI, 5.3.1.9, Gpi-1, -2). 